\title{
Increased levels of circulating free insulin-like growth factors in patients with non-islet cell tumour hypoglycaemia
}

\author{
J. Frystyk ${ }^{1}$, C. Skjærbæk ${ }^{1}$, J. Zapf ${ }^{2}$, H. Ørskov ${ }^{1}$ \\ ${ }^{1}$ Institute of Experimental Clinical Research, Medical Research Laboratories, Aarhus University Hospital, Aarhus, Denmark \\ ${ }^{2}$ Department of Internal Medicine, Division of Endocrinology and Metabolism, Zurich University Hospital, Zurich, Switzerland
}

\begin{abstract}
Summary Non-islet cell tumour hypoglycaemia (NICTH) is characterised by severe and recurrent fasting hypoglycaemia, and is usually caused by secretion of insulin-like growth factor-II (IGF-II) by the tumour. This induces secondary changes in the circulating levels of insulin, growth hormone $(\mathrm{GH})$, and the IGF-binding proteins (IGFBPs), resulting in an increased insulin-like hypoglycaemic activity of IGF-II. A participating role of IGF-I is not established. We measured serum levels of free IGF-I and free IGF-II, total IGF-I, total IGF-II, big IGF-II and IGFBP-1, IGFBP-2 and IGFBP-3 in patients with NICTH before $(n=14)$ and after surgical removal of the tumour $(n=3)$. A control group $(n=20)$ was included for comparison. In NICTH patients, free IGF-II was 20fold increased $(26.8 \pm 8.1$ [mean $\pm \mathrm{SEM}$ ] vs. $1.3 \pm$
\end{abstract}

$0.1 \mu \mathrm{g} / \mathrm{l}$ ), and free IGF-I was four fold increased $(2.8 \pm 0.4$ vs. $0.7 \pm 0.1 \mu \mathrm{g} / \mathrm{l})$, as compared to control subjects $(p<0.0001)$. In accordance with earlier observations levels of total IGF-I, total IGF-II, and IGFBP-3 were decreased, whereas IGFBP-1 and IGFBP-2 were increased in NICTH (all $p$-values $<0.05$ ). The highly elevated levels of free IGF-I and free IGFII most likely imply a considerable hypoglycaemic insulin-like activity, and may, by negative feedback explain the marked suppression of the GH/IGF-I axis observed in NICTH. Finally, free IGF-II seems to be a powerful biochemical marker in the diagnosis of NICTH. [Diabetologia (1998) 41: 589-594]

Keywords NICTH, free IGF-I, free IGF-II, IGFBPs, total IGF-I, total IGF-II.
Non-islet cell tumour hypoglycaemia (NICTH) is a relatively rare syndrome defined by the presence of a solid tumour and severe recurrent fasting hypoglycaemia, which develops despite low or immeasurable levels of serum insulin [1-4]. The tumours are believed to cause hypoglycaemia by increasing the insulin-like activity of the circulating insulin-like growth

Received: 21 October 1997 and in final revised form: 15 December 1997

Corresponding author: J. Frystyk, MD, PhD, Institute of Experimental Clinical Research, Aarhus Kommune Hospital, Nørrebrogade 44, DK-8000 Aarhus C, Denmark.

Abbreviations: NICTH, non-islet cell tumour hypoglycaemia; IGF, insulin-like growth factor; IGFBP, insulin-like growth factor-binding protein; GH, growth hormone; ALS, acid labile subunit; kDa, kilo Dalton; TR-IFMA, time-resolved immunofluorometric assay; CV, coefficient of variation; HSA, human serum albumin. factor (IGF) system. Firstly, almost all tumours involved in NICTH have increased expression of IGFII mRNA and contain elevated protein levels of big IGF-II, i.e. partially processed proIGF-II $[4,5]$. Big IGF-II is present in small amounts in normal serum [6], but highly elevated in serum from most patients with NICTH [7-9], and big IGF-II has been reported to have relatively high insulin-like activity in vitro [9].

Secondly, NICTH is characterised by major changes in the composition of the circulating IGF-binding proteins (IGFBPs), which are important regulators of IGF-bioavailability [10]. In NICTH, the levels of serum total IGF-II (including normal and big IGF-II) are often within the normal range, or only modestly elevated [2-4]. Therefore, it appears more likely that changes in the bioavailability rather than in the absolute levels of IGF-II are of importance in the induction of hypoglycaemia. Normally, about $80-90 \%$ of the circulating IGF immunoreactivity is carried in a 


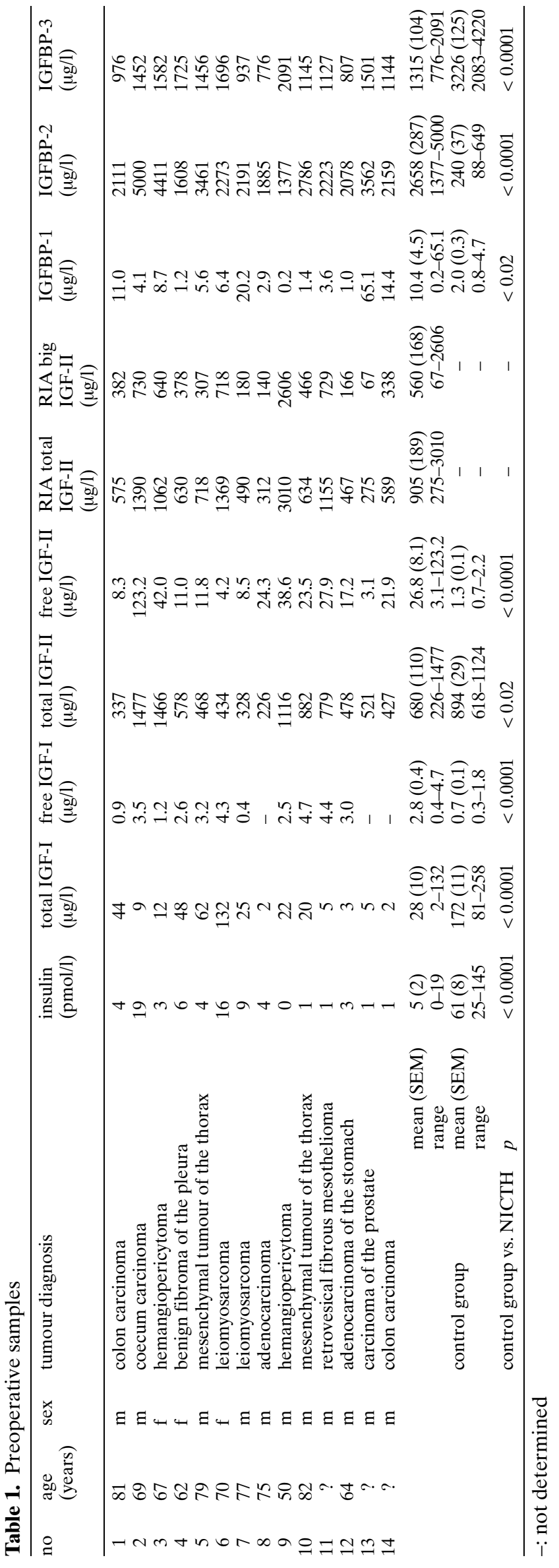

ternary 150 kilo Dalton $(\mathrm{kDa})$ growth hormone $(\mathrm{GH})$ dependent complex together with IGFBP-3 and a large non-IGF binding glycoprotein, the acid labile subunit (ALS). This complex is, due to its size, restricted to the circulation [5]. The remaining IGFs circulate almost exclusively as binary IGF:IGFBP complexes of about $30-50 \mathrm{kDa}$, leaving less than $1 \%$ in the free form [11]. In NICTH, the secretion of GH is suppressed [3], and this results in a reduction in the levels of the GH dependent peptides ALS, IGFBP-3 and IGF-I, and thus ternary complex formation [4, 12]. Levels of IGFBP-2, the second most abundant IGFBP, and IGFBP-1 are, on the other hand, increased $[5,13]$. Whereas the mechanisms regulating IGFBP-2 are still unclear [14], the increase in levels of IGFBP-1 is secondary to the hypoinsulinaemia [15]. Finally, the ability of big IGF-II:IGFBP-3 to combine with ALS forming the ternary complex is subnormal $[9,16]$. These changes cause a shift in the molecular distribution of the IGFs, and in NICTH as much as $80 \%$ of the circulating IGF-II is reported to be carried in the binary complexes and hence, to have access to the interstitial space [17]. It is likely that patients with NICTH have increased synthesis and turnover of IGF-II at the same time, and therefore only modest changes in the circulating levels of serum total IGF-II $[2,3]$.

Our previous observations have suggested that free IGFs contribute only marginally to the glucohomeostasis in the normal state [18]. However, in NICTH free IGF-II most likely plays a major role. Daughaday et al. [12] recently reported that levels of "free IGF-II" (determined by chromatography) were highly elevated in patients with NICTH and suggested that this largely explained the marked hypoglycaemia. Chromatography appears, however, not to be well suited for determination of free IGFs, primarily because it does not allow maintenance of the in vivo equilibrium between free and bound peptide [11]. We have, therefore, examined circulating levels of free and total IGFs and IGFBPs in preoperative and postoperative serum samples from patients with severe hypoglycaemia, measuring free IGF-I and free IGF-II using an ultrafiltration technique designed to obtain in vivo concentrations.

\section{Subjects, materials and methods}

We studied serum from 14 patients with NICTH; the available clinical data are listed in Table 1 . NICTH was defined by the concomitant presence of a large tumour, recurrent and severe hypoglycaemia and low or immeasurable levels of serum insulin. Big IGF-II levels in some of the patients have been published previously [9], and primarily metabolic data from one patient has been published before [19]. The study included preoperative serum samples from 14 patients with NICTH, as well as preliminary data on 3 postoperative patients. For comparison, fasting serum samples obtained from 20 healthy sub- 

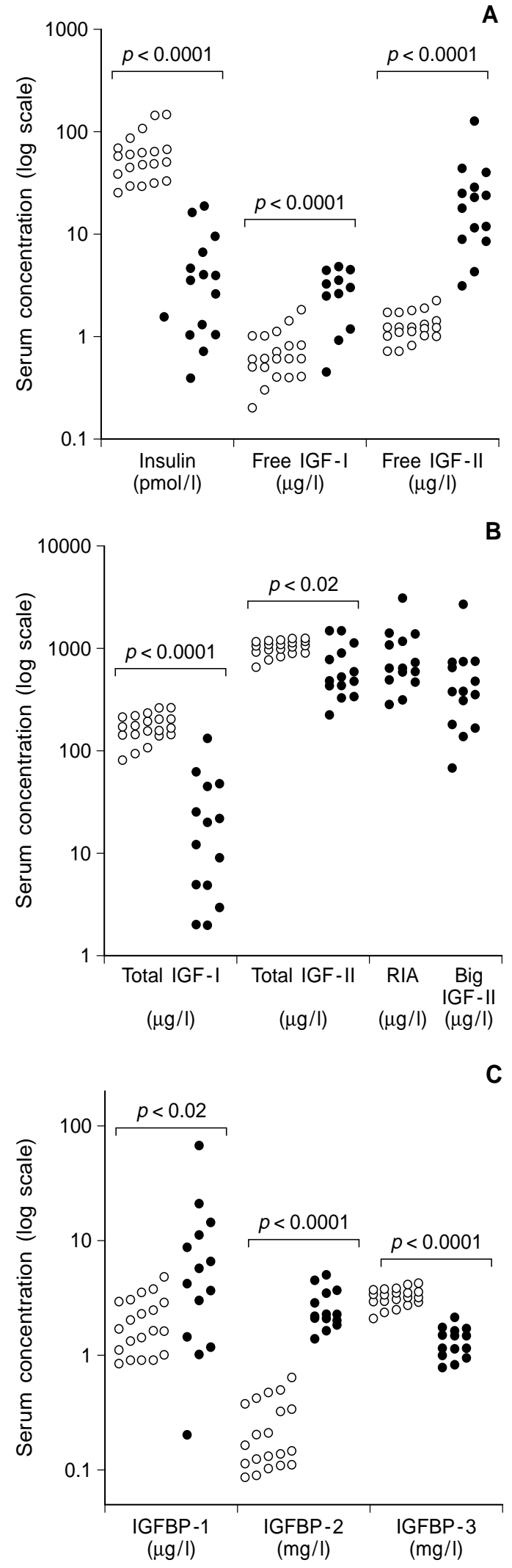

Fig. 1. Individual levels of insulin, free IGF-I and free IGF-II A; total IGF-I, total IGF-II (Aarhus TR-IFMA), total IGF-II (Zurich RIA) and big IGF-II (Zurich RIA) B; and IGFBP-1, IGFBP-2 and IGFBP-3 C. (O) controls, (O) patients with NICTH. $p$-values are indicated. Please note that the Y-axes are logarithmic jects (10 females and 10 males) served as controls. This group was characterised by an age of $51 \pm 1$ (39-59) years (mean \pm SEM [range]), a weight of $87 \pm 3$ (66-103) $\mathrm{kg}$, a BMI of $29.7 \pm 0.7(25.2-37.1) \mathrm{kg} / \mathrm{m}^{2}$ (NICTH patients are usually wellnourished), a normal fasting blood glucose of $4.4 \pm 0.1$ (3.5-5.6) $\mathrm{mmol} / \mathrm{l}$ and a fasting serum insulin of $61 \pm 8(25-145)$ $\mathrm{pmol} / \mathrm{l}$. The study was conducted in accordance with the Helsinki Declaration with amendments.

All samples were analysed in duplicates unless otherwise stated. IGF-I and IGF-II were determined by two in-house non-competitive monoclonal antibody based time-resolved immunofluorometric assays (TR-IFMAs) [20]. These assays are characterised by high sensitivity (detection limit was 2.5 $\mathrm{ng} / \mathrm{l}$ [IGF-I]) and $10 \mathrm{ng} / \mathrm{l}$ [IGF-II]) and specificity (the IGF-I and IGF-II cross reactivity in heterologous assays was $<0.0002 \%)$. Serum total IGF-I and IGF-II were determined in acid ethanol serum extracts with a within-assay and in between-assay coefficient of variation (CV) averaging less than $5 \%$ and $10 \%$, respectively [20]. In addition, serum big and total IGF-II were isolated using acid Biogel P-60 chromatography, and measured by RIA as previously described [9]. Serum free IGF-I and IGF-II were determined using ultrafiltration by centrifugation (Amicon YMT 30 ultrafiltration membranes and MPS-1 supporting devices, Amicon, Beverly, Mass., USA) [11]. Normally, serum from healthy subjects can be diluted 20 times in Krebs-Ringer bicarbonate buffer $(\mathrm{pH}$ 7.4, $50 \mathrm{~g} / \mathrm{l}$ human serum albumin [HSA]) without changing the concentration of free IGF [11]. A pilot study performed on serum from a patient with NICTH showed, however, that in this case serum could not be diluted prior to ultrafiltration without altering the concentration of free IGF-II. In the undiluted state, the concentration of free IGF-II was $106 \mu \mathrm{g} / \mathrm{l}$, but decreased to 53, 22 and $11 \mu \mathrm{g} / \mathrm{l}$ following a dilution of 1:5, 1:10 and 1:20, respectively. Similar observations have been made in experiments with rats, which are characterized by levels of free IGF-I that are approximately 100 times higher than in humans, i.e. in the range of what is observed in patients with NICTH [21]. Therefore, in samples from patients with NICTH, free IGF-I and IGF-II were determined in undiluted serum, whereas samples from the control subjects were diluted 1:11 as previously described [11]. Before centrifugation (at $37^{\circ} \mathrm{C}$ and $300 \mathrm{~g}$ ), all samples were adjusted to $\mathrm{pH} 7.4$ with $\mathrm{CO}_{2}$, and equilibrated for $30 \mathrm{~min}$ at $37^{\circ} \mathrm{C}$. Controls were analysed in triplicates with a CV of $20.9 \%$ (free IGF-I) and $24.7 \%$ (free IGF-II). The volume of serum from patients with NICTH was sparse, and therefore, free IGF-I and IGF-II were analysed in single determinations. Serum free IGF-II was, however, analysed in 4 different dilutions (1:51, 1:102, 1:204 and 1:408). The $\mathrm{CV}$ of the 4 different dilutions averaged $20.0 \%$, and samples diluted in parallel with the calibration curve (data not shown). The ultrafiltrates obtained sufficed for determination of free IGF-I in 11 out of the 14 patients with NICTH only.

IGFBP-1 was measured by ELISA (Medix Biochemica, Kainiainen, Finland), IGFBP-2 and IGFBP-3 by RIA and immunoradiometric assay (IRMA) (Diagnostic System Laboratories Inc., Webster, Tex., USA), GH by TR-IFMA (Wallac Oy, Turku, Finland), and insulin by ELISA (Dako A/S, Glostrup, Denmark).

Statistical analysis. Patients with NICTH were compared to control subjects using Student's unpaired $t$-test (parametric data) or Mann Whitney's rank sum test (non-parametric data). Preoperative and postoperative samples from patients with NICTH were not statistically compared due to a limited number of subjects $(n=3)$. Data are given as mean \pm SEM, and range when appropriate. A $p$-value less than 0.05 was considered statistically significant. 
Table 2. Postoperative samples

\begin{tabular}{|c|c|c|c|c|c|}
\hline no & $\begin{array}{l}\text { post-operative } \\
\text { sample time }\end{array}$ & $\begin{array}{l}\text { total IGF-I } \\
(\mu \mathrm{g} / \mathrm{l})\end{array}$ & $\begin{array}{l}\text { free IGF-I } \\
(\mu \mathrm{g} / \mathrm{l})\end{array}$ & $\begin{array}{l}\text { total IGF-II } \\
(\mu \mathrm{g} / \mathrm{l})\end{array}$ & $\begin{array}{l}\text { free IGF-II } \\
(\mu \mathrm{g} / \mathrm{l})\end{array}$ \\
\hline 5 & 22 months & 44 [62] & $-[3.2]$ & 671 [468] & 1.2 [11.8] \\
\hline 9 & 3.5 months & 319 [22] & $0.9[2.5]$ & 844 [1116] & $2.3[38.6]$ \\
\hline 10 & $1 \mathrm{~h}$ & 20 [20] & $0.5[4.7]$ & 575 [882] & $4.6[23.5]$ \\
\hline 10 & $6 \mathrm{~h}$ & $30[20]$ & $0.2[4.7]$ & 438 [882] & $0.3[23.5]$ \\
\hline 10 & $12 \mathrm{~h}$ & 47 [20] & 0.3 [4.7] & $520[882]$ & $0.1[23.5]$ \\
\hline 10 & $24 \mathrm{~h}$ & 27 [20] & 0.2 [4.7] & 480 [882] & 0.4 [23.5] \\
\hline 10 & 9 days & 52 [20] & 0.5 [4.7] & 731 [882] & $1.5[23.5]$ \\
\hline
\end{tabular}

For comparison, preoperative levels are given in brackets; -: not determined

\section{Results}

As expected, NICTH was characterised by markedly reduced insulin levels being below the fasting level of the controls $(p<0.0001)$ (Fig. 1A). In all patients with NICTH the concentration of free IGF-II exceeded that of the control subjects $(p<0.0001)$ (Fig.1A). Free IGF-I was also significantly increased and above the upper limit of the controls in 8 out of 11 patients $(p<0.0001)$ (Fig. 1A). Total IGF-I $(p<$ $0.0001)$ (Fig. 1B) and total IGF-II $(p<0.02)$ (Fig. 1B) were significantly reduced in NICTH using the twosite monoclonal IGF TR-IFMAs. Big IGF-II (Fig.1B) has previously been shown to be elevated in some of the NICTH patients included in this study: about $50 \%$ of total IGF-II was accounted for by big IGF-II, whereas in normal serum only $10 \%$ was present as big IGF-II [9]. Similar levels of total IGF-II were obtained using either RIA or TR-IFMA ( $p=$ $0.3)$, although some inconsistency was observed. In patients with NICTH, both IGFBP-1 $(p<0.02)$ and IGFBP-2 $(p<0.0001)$ were increased, whereas IGFBP-3 was decreased $(p<0.0001)$, when compared to control subjects (Fig.1C). All individual data have been summarized in Table 1. The preliminary postoperative data showed that removal of the tumour normalised free IGF-I and free IGF-II, big IGF-II [9] and total IGF-I, whereas total IGF-II remained unaltered within the normal range (Table 2).

In NICTH patients, free IGF-II was positively correlated with serum total IGF-II (TR-IFMA) $(r=0.75$; $p<0.005)$ and serum IGFBP-2 $(r=0.61 ; p<0.03)$. Levels of big IGF-II and free IGF-II were positively correlated after transformation of raw data to reciprocal values $(r=0.65 ; p<0.02)$, whereas no significant correlations between levels of free IGF-I and big IGF-II, or between free IGF-I and free IGF-II were observed. These were, however, correlated in the control group $(r=0.71 ; p<0.0005)$. Insulin and IGFBP-1 were inversely correlated in the control group only $(r=-0.57 ; p<0.01)$.

\section{Discussion}

In the present study of patients with NICTH the preoperative level of free IGF-I and free IGF-II was highly elevated. Thus, both peptides may participate in provoking hypoglycaemia. The increase in free IGF-I is a novel observation, and may participate in the suppression of the GH/IGF-I axis seen in NICTH [2-4]. Our findings of decreased circulating levels of total IGF-I, total IGF-II and IGFBP-3 and of increased levels of big IGF-II, IGFBP-1 and IGFBP-2 are in accordance with previous observations [2-5].

Using reverse phase neutral Sep Pak chromatography [22] Daughaday et al. measured "free IGF-II" in eight patients with NICTH and found levels ranging from approximately $120-310 \mu \mathrm{g} / \mathrm{l}$, compared to a control level of 7-23 $\mu \mathrm{g} / 1$ [12]. Both ranges are considerably higher than reported here, which may primarily be explained by methodological differences. Firstly, Sep Pak separation does not permit free IGFs to be isolated at in vivo conditions. Secondly, the isolated free IGFs may include some IGFBP-complexed IGFs, which are not completely separated on the neutral Sep Pak column [22]. Thirdly, it is likely that the Sep Pak column is able to extract bound IGFs from some of the labile IGF:IGFBP complexes. Thus, we believe that Sep Pak separation of free from bound IGFs results in an overestimation of free IGF levels, and that a normal level of $7-23 \mu \mathrm{g} / \mathrm{l}$ of free IGF-II is far too high. Because C-18 reverse phase cartridges appear to be less suited for determination of free IGFs, we developed an ultrafiltration method that enables us to isolate free IGFs at physiological conditions (temperature, $\mathrm{pH}$ and ionic composition) without grossly altering the in vivo equilibrium between free and IGFBP-complexed IGF [11] (ultrafiltration is regarded as the gold standard for determination of free thyroid hormones). With this technique we have previously shown that free IGF-I shows meaningful variations in certain physiological and pathophysiological situations [11, 23-25].

So far, most studies of NICTH have explained the recurrent hypoglycaemia with increased levels of big IGF-II and with the shift in circulating IGF-II from the ternary $150 \mathrm{kDa}$ to the binary $40 \mathrm{kDa}$ complex. 
These changes are reversed following surgical removal of the tumour [2-4,26], or following treatment with $\mathrm{GH}$ and prednisolone, which both alleviate the hypoglycaemia by stimulating (via different mechanisms) the formation of the ternary complex [5, 27, 28]. Only recently free IGF-II has been suggested as being of major importance in provoking hypoglycaemia in NICTH [12]. Our results support and extend the theory to include free IGF-I as a possible cause of hypoglycaemia. In NICTH patients, the combined levels of free IGF-I plus free IGF-II ranged from about 3 to $127 \mu \mathrm{g} / \mathrm{l}$ as compared to $1-4 \mu \mathrm{g} / \mathrm{l}$ in normal control subjects. From in vitro studies in isolated mouse soleus muscle it appears that the half-maximal effect of IGF-I on glucose uptake, glycolysis and glycogen synthesis is between 35 and $80 \mu \mathrm{g} / \mathrm{l}$ [29]. Assuming a similar potency for IGF-II one would guess that serum levels of about $20 \mu \mathrm{g} / \mathrm{l}$ of free IGF, which were present in 8 out of 14 tumour patients, would be sufficient to cause hypoglycaemia.

The mechanisms responsible for the elevated serum levels of free IGF-I and free IGF-II are not clear. We believe that the elevation is secondary to the increased synthesis of big IGF-II by the tumour, displacing IGF-I and IGF-II from the IGFBPs. This view is supported by the significant positive correlation between levels of free IGF-II and big IGF-II $(r=0.65$; $p<0.02$ ). However, further studies are needed.

Levels of free IGF-I were fourfold increased in patients with NICTH, when compared to control subjects, and these changes markedly contrasted with the sixfold reduction in total IGF-I. Free IGF-I was, however, not as grossly elevated as free IGF-II in the patients with NICTH, but the inhibitory effect of IGF-I on the pituitary is reported to be stronger than that of IGF-II $[30,31]$. Therefore, both peptides may contribute to the marked suppression of $\mathrm{GH}$, which may aggravate the hypoglycaemia.

Three patients with NICTH were studied postoperatively, and as judged from the measurements all patients underwent a successful tumour removal: levels either normalised or near-normalised. As observed in patient no. 10 these changes took place very rapidly.

In conclusion, this study gives further evidence for a pathogenic role of free IGF-II in tumour induced hypoglycaemia. In addition, the increased level of free IGF-I may in part, by negative feedback contribute to the suppressed $\mathrm{GH}$ secretion observed in NICTH. The study also shows that free IGF-II is a powerful biochemical discriminator in the diagnosis of NICTH.

Acknowledgements. This study was supported by grants from the Danish Health Research Council (grant no. 9601222), Danish Health Research Council (Aarhus University - Novo Nordisk Centre for Research in Growth and Regeneration (grant no. 9600822)), Institute of Experimental Clinical Re- search, University of Aarhus, and from the Swiss National Science Foundation (grant no. 32-31281.91). We are indebted to Mrs. K. Nyborg Rasmussen, Mrs. S. Sørensen, Mrs. J. Hansen, and Mrs. I. Bisgaard for skilled technical assistance.

\section{References}

1. Kahn CR (1980) The riddle of tumour hypoglycaemia revisited. Clin Endocrinol Metab 9: 335-360

2. Bach LA, Rechler MM (1995) Insulin-like growth factor binding proteins. Diabetes Rev 3: 38-61

3. Zapf J (1995) Insulin-like growth factor binding proteins and tumor hypoglycemia. Trends Endocrinology Metabolism 6:37-42

4. Daughaday WH (1995) The pathophysiology of IGF-II hypersecretion in non-islet cell tumor hypoglycemia. Diabetes Rev 3: 62-72

5. Baxter RC, Holman SR, Corbould A, Stranks S, Ho PJ, Braund W (1995) Regulation of the insulin-like growth factors and their binding proteins by glucocorticoid and growth hormone in nonislet cell tumor hypoglycemia. J Clin Endocrinol Metab 80:2700-2708

6. Zumstein PP, Luthi C, Humbel RE (1985) Amino acid sequence of a variant pro-form of insulin-like growth factor II. Proc Natl Acad Sci U S A 82: 3169-3172

7. Daughaday WH, Kapadia M (1989) Significance of abnormal serum binding of insulin-like growth factor II in the development of hypoglycemia in patients with non-islet-cell tumors. Proc Natl Acad Sci U S A 86:6778-6782

8. Shapiro ET, Bell GI, Polonsky KS, Rubenstein AH, Kew MC, Tager HS (1990) Tumor hypoglycemia: relationship to high molecular weight insulin-like growth factor-II. J Clin Invest 85:1672-1679

9. Zapf J, Futo E, Peter M, Froesch ER (1992) Can "big" insulin-like growth factor II in serum of tumor patients account for the development of extrapancreatic tumor hypoglycemia? J Clin Invest 90: 2574-2584

10. Zapf J (1995) Physiological role of the insulin-like growth factor binding proteins. Eur J Endocrinol 132:645-654

11. Frystyk J, Skjærbæk C, Dinesen B, Ørskov H (1994) Free insulin-like growth factors (IGF-I and IGF-II) in human serum. FEBS Letters 348: 185-191

12. Daughaday WH, Trivedi B, Baxter RC (1995) Abnormal serum IGF-II transport in non-islet cell tumor hypoglycemia results from abnormalities of both IGF binding protein-3 and acid labile subunit and leads to elevation of free IGF-II. Endocrine 3:425-430

13. Zapf J, Schmid C, Guler HP et al. (1990) Regulation of binding proteins for insulin-like growth factors (IGF) in humans. Increased expression of IGF binding protein 2 during IGF I treatment of healthy adults and in patients with extrapancreatic tumor hypoglycemia. J Clin Invest 86: 952-961

14. Bereket A, Lang CH, Blethen SL, Wilson TA (1995) Insulin-like growth factor-binding protein-2 and insulin: studies in children with type 1 diabetes mellitus and maturity-onset diabetes of the young. J Clin Endocrinol Metab 80:3647-3652

15. Lee PD, Conover CA, Powell DR (1993) Regulation and function of insulin-like growth factor-binding protein-1. Proc Soc Exp Biol Med 204: 4-29

16. Baxter RC, Daughaday WH (1991) Impaired formation of the ternary insulin-like growth factor-binding protein complex in patients with hypoglycemia due to nonislet cell tumors. J Clin Endocrinol Metab 73:696-702 
17. Binoux M, Hossenlopp P (1988) Insulin-like growth factor (IGF) and IGF-binding proteins: comparison of human serum and lymph. J Clin Endocrinol Metab 67: 509-514

18. Frystyk J, Grøfte T, Skjærbæk C, Ørskov H (1997) The effect of oral glucose on serum free insulin-like growth factor-I and -II in healthy adults. J Clin Endocrinol Metab 82:3124-3127

19. Møller N, Frystyk J, Skjærbæk C et al. (1996) Systemic and regional tumour metabolism in a patient with non-islet cell tumour hypoglycaemia: role of increased levels of free insulin-like growth factors. Diabetologia 39: 534-535

20. Frystyk J, Dinesen B, Ørskov H (1995) Non-competitive time-resolved immunofluorometric assay for determination of human insulin-like growth factor I and II. Growth Regul 5:169-176

21. Frystyk J, Grønbæk H, Skjærbæk C, Flyvbjerg A (1995) Effect of hyperthyroidism on circulating levels of free and total IGF-I and IGFBPs in rats. Am J Physiol 269:E840-E845

22. Hizuka N, Takano K, Asakawa K et al. (1991) Measurement of free form of insulin-like growth factor I in human plasma. Growth Regul 1:51-55

23. Frystyk J, Vestbo E, Skjærbæk C, Mogensen CE, Ørskov H (1995) Free insulin-like growth factors in human obesity. Metabolism 44 (suppl 4):37-44

24. Kaal A, Frystyk J, Skjærbæk C et al. (1995) Effects of intramuscular microsphere-encapsulated octreotide on serum growth hormone, insulin-like growth factors (IGFs), free IGFs, and IGF-binding proteins in acromegalic patients. Metabolism 44 (suppl. 1):6-14
25. Skjærbæk C, Vahl N, Frystyk J et al. (1997) Serum free insulin-like growth factor-I in growth hormone deficient adults before and after growth hormone replacement. Eur J Endocrinol 132: 132-137

26. Zapf J, Hauri C, Futo E et al. (1995) Intravenously injected insulin-like growth factor (IGF) I/IGF binding protein-3 complex exerts insulin-like effects in hypophysectomized, but not in normal rats. J Clin Invest 95:179-186

27. Hunter SJ, Daughaday WH, Callender ME et al. (1994) A case of hepatoma associated with hypoglycaemia and overproduction of IGF-II (E-21): beneficial effects of treatment with growth hormone and intrahepatic adriamycin. Clin Endocrinol (Oxf) 41: 397-401

28. Teale JD, Blum WF, Marks V (1992) Alleviation of non-islet cell tumour hypoglycaemia by growth hormone therapy is associated with changes in IGF binding protein-3. Ann Clin Biochem 29:314-323

29. Poggi C, Le Marchand Brustel Y, Zapf J, Froesch ER, Freychet P (1979) Effects and binding of insulin-like growth factor I in the isolated soleus muscle of lean and obese mice: comparison with insulin. Endocrinology 105: 723-730

30. Weber MM, Melmed S, Rosenbloom J, Yamasaki H, Prager D (1992) Rat somatotroph insulin-like growth factor-II (IGF-II) signaling: role of the IGF-I receptor. Endocrinology 131:2147-2153

31. Jones JI, Clemmons DR (1995) Insulin-like growth factors and their binding proteins: biological actions. Endocr Rev 16: 3-34 